\title{
Gender dimension of human trafficking. Interferences from the legal culture. The Spanish case
}

\author{
Patricia Faraldo Cabana, PhD \\ Faculty of Law, Department of Public Law, University of A Corunna, Spain \\ E-mail: yrinas@udc.es
}

\begin{abstract}
Taking into account the gender dimension of trafficking in human beings is essential to ensure adequate support for the female victims as well as effective prevention and the prosecution of traffickers. Directive 2011/36/EU of 5 April 2011 on preventing and combating trafficking in human beings and protecting its victims from a gender perspective recognised that this is a gender-specific phenomenon, affecting men and women in different ways. Therefore, the Directive obliged member states to take into account the gender dimension of trafficking, to develop knowledge on the gender specificities of the way men and women are recruited and exploited, the gender consequences of the various forms of trafficking and potential differences in the vulnerability of men and women to victimisation and its impact on them.

This paper aims to verify in depth the compliance of Spain in terms of application of the Directive, in particular the adoption of a gender perspective. It will do it from the viewpoint that legal actors such as judges, practitioners and legislators need to work with some supposedly consensual idea of legal culture as a regulative ideal when they argue what the European law requires. The main hypothesis is that the Spanish legal culture regarding human trafficking interferes with the EU policy on the matter, especially the fuller implementation of its gender aspects, rendering the transposition and implementation of different elements of the EU Anti-Trafficking Directive contradictory and ineffective. To support her conclusions, the author offers contextual information based on pre-legislative and academic discussions related to the
\end{abstract}


legislative actions taken by the government to transpose the EU Anti-Trafficking Directive from a gender perspective.

Keywords: Human trafficking, legal culture, gender perspective, migration control, prostitution

\section{Introduction}

It has been recently published the European Implementation Assessment on the implementation of Directive 2011/36/EU of the European Parliament and of the Council of 5 April 2011 on preventing and combating trafficking in human beings and protecting its victims, and replacing Council Framework Decision 2002/629/JHA (henceforth 'the Directive'), drawn up by the Ex-Post Impact Assessment Unit of the Directorate for Impact Assessment and European Added Value, within the European Parliament's Directorate-General for Parliamentary Research Services. It concludes that there is an uneven implementation of the Directive's requirements across the Member States, in particular related to the gender dimension, which is not taken into account in the application of the Directive by some Member States. There is a shortfall of implementation of gender-specific measures in dealing with this social problem. When analysing the Spanish case, it is said that, 'despite efforts made by Spain since the adoption of the Directive, there continues to be an ineffective application of a gender perspective both in terms of legal and policy framework and in terms of implementation of measures required by the Directive' (European Parliament 2016: 236).

The next section of this Article analyses the European standard on tackling human trafficking from a gender perspective, represented by the Directive. The third section shows with more detail the outcome of the European Implementation Assessment with regards to Spain. The fourth section offers a critical discussion of what is entailed by speaking of an 'uneven implementation' of the Directive's requirements related to the gender dimension of human trafficking when analysing the Spanish case. The Article then goes on to show there are inherent difficulties when implementing an international or European standard in national contexts, discussing the relevance of the role of legal culture in shaping the link between the way in which the problem of trafficking is defined at the European level and how it is implemented at the national 
level. In the fifth section an in-depth study of the Spanish context will show that there are two competing narratives when speaking about human trafficking, one related to illegal migration and one to human rights, and that the former is the one with more tradition and acceptance within the Spanish legal culture. The Article will end with some conclusions.

\section{The European standard: the gender dimension in the Directive 2011/36/EU}

The use of a gender-specific focus shows that human trafficking affects women and men in different ways as they are trafficked for a different purpose and have separate experiences. Worldwide statistics reported by the UNODC (UNODC Global Report 2016) and EU-wide statistics reported by the Eurostat (Eurostat 2015) indicate that the vast majority of victims of trafficking identified in the EU Member States are still women and girls subjected to trafficking for the purposes of sexual exploitation. Certainly there are also men trafficked for the purposes of labour exploitation, and a small number of boys trafficked for sexual exploitation. Over the last 10 years the percentage of men and boys among detected trafficking victims has grown up, an increase that goes almost parallel with the significant increases in the share of victims who are trafficked for forced labour (UNODC Global Report 2016: 6). However, the number of female victims dominate in all forms of human trafficking starting from its most common form, sex trafficking, through to labour trafficking and the less frequently occurring types of trafficking crimes, such as exploitation for conducting criminal activities and begging, and more recently exploitative sham marriages.

The Directive recognises 'the gender-specific phenomenon of trafficking and that women and men are often trafficked for different purposes' (Recital 3). From the perspective of the protection of victims, the Directive insists on the idea that this gender-specific perspective is part of 'an integrated, holistic, and human rights approach to the fight against trafficking in human beings' (Recital 7). Therefore, the Directive obliges EU Member States to take into account the gender dimension of trafficking when developing both preventive and repressive policies, as well as policies focusing on the protection of victims. From a preventive viewpoint, the Directive encourages Member States to develop knowledge on the gender specificities of the way 


\section{Seccurity}

men and women are recruited and exploited, the gender-specific consequences of the various forms of trafficking, and potential differences in the vulnerability of men and women to victimisation and its impact on them, as well as to develop gender-specific assistance and support measures where appropriate. In all initiatives concerning measures to discourage and reduce the demand that fosters all forms of exploitation, and measures to reduce the risk of people becoming victims of trafficking in human beings, by means of research, including research into new forms of trafficking in human beings, information, awareness-raising, and education, Member States should adopt a gender perspective (Recital 25). From a repressive viewpoint, the Directive also indicates that the level of penalties should take into account aggravating circumstances, for example, when the offence is committed against a particularly vulnerable victim. Factors that could be considered when assessing the vulnerability of a victim are, for example, gender and pregnancy. Moreover, the Directive prescribes a more severe penalty when the offence is particularly grave, 'for example when the life of the victim has been endangered or the offence has involved serious violence such as torture, forced drug/medication usage, rape or other serious forms of psychological, physical or sexual violence, or has otherwise caused particularly serious harm to the victim' (Recital 12). The seriousness of the offence could be taken into account within the framework of the execution of the sentence.

What has Spain done to implement the gender-specific perspective in national legislation and practice?

\section{The outcome of the European Implementation Assessment with regards to}

\section{Spain}

According to the European Implementation Assessment, Spain is unable to tackle all forms of exploitation and to identify and protect all victims. Two factors have been identified as relevant: first, the primary identification of trafficked women as illegal migrants, and only secondarily as victims, with the State failing to adopt a human rights approach instead of a securitizing one, a fact partly due to the ineffective application of a gender perspective; and second, the exclusive focus on trafficking for the purpose of sexual exploitation, which makes invisible victims of other forms of exploitation. 
In Spain, the double identification of trafficked women as illegal migrants and victims steadily colonised the territory of human trafficking and captured the attention of government agencies already in a consensus about a crime-control discourse in which the identity of trafficked women remains hidden behind their primary identity as illegal migrants. In such a context, the fight against trafficking is re-structured not in terms of focusing on victim's rights, but in terms of avoiding a diffuse threat to the State (Aradau 2004: 253). Due to the emphasis on the criminal prosecution, trafficked victims who are unwilling to collaborate in criminal proceedings are often denied access to protection, even though this measure has been implemented in legislation (Article 59 bis of the Spanish Immigration Act ${ }^{91}$ ). This means that the number of victims identified is much lower than the number of individuals detected in an at-risk situation, ${ }^{92}$ because if they do not show interest in collaborating with the authorities they are not even identified as victims. Since they are generally reluctant to testify and co-operate with the prosecution efforts and refuse the recovery and reflection period, they do not receive any protection measure.

Second, Spanish penal legislation formally complies with the European legal framework and punishes trafficking for labour exploitation and harvesting of bodily organs, but in practice these forms of exploitation remain hidden. Governmental action is almost exclusively focused on trafficking for purposes of sexual exploitation, considered as a form of gender violence. ${ }^{93}$ As a result, law enforcement authorities are

${ }^{91}$ By Organic Law 2/2009 of 11 December, amending the Organic Law 4/2000 (Ley Orgánica 2/2009, de 11 de diciembre, de reforma de la Ley Orgánica 4/2000, de 11 de enero, sobre derechos y libertades de los extranjeros en España y su integración social), after Spain was condemned by the Court of Justice of the European Union for non-complete alignment of national law when transposing Directive 2004/81/EC (Judgement of the Court, Sixth Chamber, of May 14, 2009 - Spain (case C-266/08)).

${ }^{92}$ According to data released by CITCO 2015, 2014 and 2013, in 2015 13,879 people at risk were detected, of which only 133 , a percentage of 0.95 , were identified as victims of human trafficking for sexual exploitation, while in 13,983 people at risk were detected and 153 were identified as victims in 2014, 1.09 per cent. In 2013 the figures were 13,159 people at risk and 264 victims, the 2 per cent. There is a preoccupying downward trend.

${ }^{93}$ Very clear in this regard, see the Comprehensive Plan to Combat Trafficking of Women and Girls for Sexual Exploitation 2015-2018 - Plan integral de Lucha contra la Trata de Mujeres y 


\section{Seccurity}

not able to identify victims of human trafficking for the purpose of labour exploitation as such. For example, the result of the 11 ex officio investigations of cases of suspected labour exploitation by the Spanish Ombudsperson (Defensor del Pueblo) was that of a total of 99 presumed victims not even one of them was actually deemed by law enforcement authorities to be a victim of human trafficking (Defensor del Pueblo 2012: $69 \mathrm{ff}$.$) .$

Given these results, the report's authors conclude that Spain's transposition of the Directive has not created an appropriate human rights framework to address trafficking and adequately protect and promote the rights of trafficking victims. This lack of a human rights framework is the basis for the Government's inability to create the necessary infrastructure to apply a gender perspective. The framework is clearly lacking in terms of, inter alia, strategies to address trafficking for means other than sexual exploitation, appropriate protocols to identify girls that are trafficked to Spain and appropriate mechanisms to collect data. The failure to properly implement the Directive means that there is a lack of a gender perspective and inadequate structure in which identification is taking place. The direct result of this failure is the ongoing presence of obstacles for the recognition of trafficking victims and their access to rights. (European Parliament 2016: 236)

Despite recognising standardising efforts made by Spain since the adoption of the Directive, this independent evaluation indicates that level of transposition of the Directive and the existing legal mechanisms aimed at tackling human trafficking are not giving the expected results. Difficulties associated with the lack of a gender perspective and the dominance of a crime control approach have limited the usefulness of the adopted measures. The total numbers of identified and protected victims remain at very modest levels.

Should we conclude that the implementation of the European standard represented by the Directive has failed in Spain? By no means. Some difficulties are inherent to the process of implementing international and European standards at national level. In the next section we will analyse the inherent difficulties of implementing European standards.

Niñas con Fines de Explotación Sexual 2015-2018 -, pp. 14-19, elaborated by the Ministry of Health, Social Services and Equality. 


\section{Concerning the inherent difficulties of implementing European standards}

The European standard concerning human trafficking is established in the Directive. As we have seen, the Directive recognizes that human trafficking has a clear gender dimension that should be taken into account when implementing measures related to victim identification, protection, assistance, prevention, and repression of the crime. However, the implementation is by no means easy, as shown by the European Implementation Assessment of the Directive: 'even in the MS which have in principle implemented the Directive's requirements, its effective implementation on the ground appears uneven. This is particularly true when one takes into account its gender dimension, despite the fact that this is an important element of the Directive as stipulated in its Article 1' (European Parliament 2016: 12). An effective implementation becomes even more difficult in countries in which, on the one hand, the gender perspective has produced a concentration of efforts in human trafficking for sexual exploitation, ignoring other forms of exploitation and, on the other hand, human trafficking has been tackled with a crime control approach, in the context of the fight against illegal migration. This is the case of Spain.

But before analysing the reasons for this, it is important to warn of the need to avoid the common tendency of reducing the problems surrounding the implementation of European standards to the scope of the practical difficulties of implementing them. So, to start with, we need to define exactly what is understood as the success or failure of a European standard. For example, although there is no doubt that many countries still have a low level of compliance with the Directive, it is generally recognised that its transposition has led to greater efforts being made, which in turn, increases the level of awareness of the political elite regarding the need to do something about this, and, therefore, this also increases the efforts made concerning this issue.

Secondly, European standards normally tend to mask the differences between those promoting the action. Discrepancies about the 'real meaning' of these agreements are common and constant. It could be said that each country has its own way of implementing them, as the concept of legal culture would suggest. ${ }^{94}$ If indeed

\footnotetext{
${ }^{94}$ The broad definition of legal culture used here is one way of describing relatively stable tendencies of lawful social attitudes and behaviours. The identifying elements of legal culture range from facts concerning institutions, like the number and role of lawyers or the ways in
} 


\section{Seccurity}

national differences do exist, what should be done about this? Does something really need to be done? From a certain point of view these differences present an obstacle that has to be overcome through harmonisation and cooperation. For example, one of the objectives of the Directive was to 'strengthen policies to prevent trafficking in human beings, including measures to discourage and reduce the demand that fosters all forms of exploitation, and measures to reduce the risk of people becoming victims of trafficking in human beings, by means of research, including research into new forms of trafficking in human beings, information, awareness-raising, and education' (Recital 25). One could think that this objective is in danger because of the uneven implementation of the Directive. From another point of view, however, it could be argued that implementation should, in fact, be different if the contexts and challenges themselves are. It may be that maintaining political, legal and cultural diversity is an intrinsic value, even if it does lead to different results when implementing European standards.

With regards human trafficking, although communication between the national monitoring systems with authority over this matter is improving, there is still very little cooperation or cross-fertilisation of ideas across the national borders. So, the Council of Europe, the European Union, the United Nations, and other worldwide institutions continue to offer general advice intended to be universally valid about how to effectively respond to the problem of human trafficking. Perhaps, however, we should first understand the specific features of each legal culture before we can overcome them, especially when these differences also affect the way in which European standards, which are intended to be intercultural but are not in reality, are interpreted and followed. The point is that countries make use of European standards in line with their national way of understanding them, locally, often with aims that are essentially local rather than cooperative. We should understand better this kind of approach in order to improve national efforts in the fight against human trafficking. The European Implementation Assessment also recognises that the detected shortcomings are often

which judges are allocated and controlled, to different forms of conduct like the indices of judicialisation and prisonisation, and, at the other end of the scale, more nebulous aspects of ideas, values, aspirations and mentalities. Like general culture, legal culture encompasses who we are, not just what we do (Nelken 2004: 1-26). Further discussion about this term can be found in Nelken (1997) and Nelken and Feest (2001). Specifically on why this term is preferable to others like legal system, juridical tradition, legal mentality or juridical ideology, Nelken (2006: 200, 208-211). 


\section{Securianues}

dependent on specific national contexts. In the next section a brief description of the Spanish legal context will help us to identify the causes of the main problems detected by the European Implementation Assessment.

\section{The Spanish legal context}

In this section two intertwined aspects will be explored, both identified by the European Implementation Assessment as the most relevant factors when explaining the Spanish lack of compliance. First, the link between human trafficking and prostitution, which resulted in a subsequent connection between human trafficking and gender violence that ended in the invisibility of other forms of trafficking that are not for purposes of sexual exploitation. This viewpoint can be framed within the myth of white slavery (Maqueda Abreu 2009a, 2009b; Puente Aba and Iglesias Skulj 2015: 72), which stills permeates world politics on the topic today (Doezema 2000, 2010). Second, the link between human trafficking and illegal migration, which ended in the securitization of the entire legal framework and the relegation of a human rights approach to a secondary place behind the crime control paradigm that dominates the fight against human trafficking in Spain.

\section{On the link between human trafficking and prostitution}

Up to the late 1980s, most members of the Spanish feminist movement conceptualised prostitution as an extreme form of women's exploitation, a position that usually coincided with the abolitionist legal approach (Valiente 2004: 210). Since then, some Spanish feminists began to state that there are two types of prostitutes, those who work voluntarily and those who are forced into prostitution by others, and that the state should actively fight forced prostitution but not free sex work (Garaizábal 1991; Pineda 1995: 108-109).

Despite the lively discussion inside the feminist movement, the parliamentary debate that led to the 1995 Spanish Penal Code hardly contained any reference to prostitution (Valiente 2004: 209-210), even though the new code contained important reforms regarding its regulation. It no longer defined promoting the prostitution of 
others or benefiting from it as a crime, except in the case of prostitution of minors and legally incapacitated people, but punished people who forced others to be prostitutes. In spite of implicitly distinguishing between voluntary and forced prostitution (Carracedo Bullido 2001: 155-157), the new code coincided with the goals of those in favour of regulation only to a certain extent (Garaizábal 1991: 10).

At the time of the enactment of the 1995 Penal Code no reference at all was made to human trafficking. ${ }^{95}$ The first legal intervention on human trafficking for sexual exploitation dates back to 1999, when the 1995 Spanish Penal Code was revised by Organic Law 11/1999 of 30 April to include it as a new crime (Article 188), while at the same time modifying some aspects of the regulation of crimes related to prostitution. A year later, in 2000, the new Immigration Act (Organic Law 4/2000 of January 11, 2000 on the rights and freedoms of foreigners in Spain and their social integration - Ley Orgánica 4/2000, de 11 de enero, sobre derechos y libertades de los extranjeros en España y su integración social) offered permanent residence and work permits to illegal immigrants trafficked into Spain and forced into prostitution if they denounced their traffickers or co-operated with public authorities in the prosecution of these traffickers (Article 55).

These two amendments were clearly based on an abolitionist approach. In fact, Spanish policies related to human trafficking were from the beginning based on the same abolitionist stance that considers prostitution as a form of sexual exploitation. ${ }^{96}$

${ }^{95}$ The previous 1944 Penal Code regulated two different offences regarding human trafficking: trafficking in workers and cooperation in illegal immigration (Article 499 bis 3) and trafficking for the purpose of prostitution (Article 442 bis a). It also included an offence of cooperation in prostitution activities and the recruitment of women for prostitution, inside or outside the Spanish territory (Article 452 bis a). The facilitation, promotion or recruitment of women under 18 years were considered criminal activities in any case (Article 452 bis b).

${ }^{96}$ This can be clearly observed both in public discourses of Spanish policy makers, such as the Minister of Labour and Social Affairs (see El Pais, February 20, 2002: 24), and official documents such as the parliamentary report on the current situation of prostitution in Spain (Informe de la ponencia para elaborar un dictamen informativo sobre la situación actual de la prostitución en nuestro pais, published in the Boletin Oficial de las Cortes Generales, sección Cortes Generales, VIII Legislatura, Serie A, April 13, 2007, 19 ff.), or the Third Gender Equality Plan 1997-2000 (III Plan para la Igualdad de Oportunidades entre Mujeres y Hombres 1997-2000, elaborated by the Spanish Women's Institute, Instituto de la Mujer 1997: 73-74, 78). It is also confirmed by experts 


\section{Seccurity}

The connection between human trafficking and prostitution was quite clear in the Comprehensive Plan to Combat Human Trafficking for Sexual Exploitation 2009-2012 (Plan integral de Lucha contra la Trata con Fines de Explotación Sexual 2009-2012), and it has been reinforced in the Comprehensive Plan to Combat Trafficking of Women and Girls for Sexual Exploitation (Plan integral de Lucha contra la Trata de Mujeres y Niñas con Fines de Explotación Sexual 2015-2018), both elaborated by the Spanish Ministry of Health, Social Services and Equality.

The strong connection between human trafficking and prostitution is quite surprising, especially because, as indicated before, Spanish penal legislation related to prostitution cannot be defined as abolitionist, but as imperfect regulationism. The explanation is to be seen in the influence exerted by the Women's Institute (Instituto de la Mujer). Its Third Gender Equality Plan 1997-2000 (III Plan para la igualdad de oportunidades entre Mujeres y Hombres 1997-2000) inspired the penal reforms related to the topic. This document used an abolitionist perspective (Valiente 2004: 221). Since then, the link between human trafficking for sexual exploitation and prostitution has been continuously reinforced by governmental actions.

The aforementioned connection has at least two important consequences. Firstly, it brands the implementation of systems for the prevention and early detection of situations of trafficking. For example, inspections in places at potential risk of human trafficking are centred in premises where prostitution is carried out. Less attention is dedicated to places where labour exploitation is a well-known reality, such as the sectors of agriculture, in particular seasonal work, textile industry, domestic service, construction and hotel/catering trade. It should be noted that there is still no plan to combat human trafficking with other purposes than sexual exploitation. This is a proof of a lack of strategic and policy instruments to combat these forms of trafficking in Spain, confirmed by the fact that there is no single institutional structure in charge of developing and co-ordinating anti-trafficking action for all types of exploitation and all victims of trafficking, including men and boys (GRETA 2013: 22-23).

Secondly, the issue of trafficking in women has been linked in the Spanish context to the wider phenomenon of gender violence (see for instance Jurado Román 2010, Gutiérrez García 2015). The task of proposing awareness-raising measures against

(Puente Aba and Iglesias Skulj 2015: 74). Nevertheless, there were no references to gender issues in the parliamentary debate that led to the 1999 amendment (Valiente 2004: 216). 


\section{Seccurity}

trafficking has been confided to the Government Office for Gender Violence since 2011, when royal decree 263/2011 of 28 February attributed to this Office the competence in the fight against all forms of gender violence, considering trafficking as a form of special vulnerability to gender violence. The preparation of protocols for detecting and reporting situations of trafficking in health, social and educational areas has been carried out through a new Common Protocol for healthcare actions against gender violence, approved on December 20, 2012. Nevertheless, this link between human trafficking with the purpose of sexual exploitation and gender violence does not mean that protection measures offered to the victims of gender violence are also offered in cases of human trafficking, because they are not.

\section{On the link between human trafficking and illegal migration}

Trafficking of human beings is located in Spain in the migration, crime, and security nexus, following international trends on this regard (Aronowitz, 2011; Spencer, 2014, pp. 299 ff.).

In 2000 an amendment of the 1995 Penal Code (by the new Immigration Act) integrated in the same article two offences, smuggling of migrants and clandestine immigration and illegal trafficking in human beings for the purpose of sexual exploitation, with the latter applied only when the illegal migrant was victim of trafficking for sexual exploitation, in which case an aggravated punishment was provided (Article 318 bis). In 2003 the offence was reformulated (by Organic Law $11 / 2003)$, but maintained the same approach by which the victim of human trafficking could only be a foreign citizen, as clearly stated by the Spanish Supreme Court in its judgement 625/2007 of July 2. In 2007 (by Organic Law 13/2007 of 19 November, Ley Orgánica 13/2007, de 19 de noviembre, para la persecución extraterritorial del tráfico ilegal o la inmigración clandestina de personas) this offence entered the limited catalogue of crimes that at that time were subject to universal prosecution by Spanish courts (see León 2010: 400-401 on the reasons that justified this change).

The lack of distinction between smuggling and trafficking was severely criticised (Pozuelo Pérez 2005; Villacampa Estiarte 2006, 2011; Daunis Rodríguez 2010, 2013, 2014; Iglesias Skulj 2011, 2012). It resulted in a purely security-based approach (León 2010: 368), 'triggering multiple initiatives intended to protect the sovereign 


\section{Securiagues}

spaces of the EU as much as the sovereign bodies of women' (Puente Aba and Iglesias Skulj 2015: 76, citing Aradau 2004: 253). Even when implementing a human rights approach this was done in the context of migration policies and the fight against the smuggling of migrants. For example, one of the objectives of the First Human Rights Plan for 2009-2011 (Plan de Derechos Humanos) was to combat human trafficking, including through closer international co-operation, but it addressed human trafficking exclusively in the context of illegal migration (GRETA 2013: 14).

The connection between human trafficking and illegal migration is also quite surprising, not so much from a conceptual viewpoint - as Outshoorn (2005: 143) observed, 'The dynamics of trafficking are best explained by migration theory' -, but from a practical one. The available statistical data show that most of the trafficked victims come from the EU (65 per cent of the registered victims in the period 20102012, according to Eurostat 2015: 41). The percentage is significantly lower in Spain (45 per cent of victims from the EU in 2011, according to Defensor del Pueblo 2012: 102203), a fact that can be explained by the early conceptualization of trafficking as an aggravated form of smuggling of illegal migrants, in this way preventing the identification of EU victims of trafficking as such. We should also remember that during this period certain provisions of the Penal Code concerning labour rights violations were used to prosecute cases of human trafficking with purposes of labour exploitation, before this form of trafficking was introduced in 2010. For example, Article 312.2 which punishes the recruitment of workers by offering them false jobs or misleading working conditions and the employment of foreigners without work permits in conditions that prejudice, reduce or remove their rights as established by law, collective agreement or employment contract - and Article 313 - which criminalises the enabling of migration of a person to another country through fake contracts, job offers or other forms of deceit. Victims of these offences were not recognised as victims of human trafficking.

In 2010 a new amendment of the 1995 Penal Code (by Organic Law 5/2010 of 22 June amending the Penal Code - Ley Orgánica 5/2010, de 22 de junio, por la que se modifica la Ley Orgánica 10/1995, de 23 de noviembre, del Código Penal) made once again independent the offence of trafficking in human beings with the purpose of sexual exploitation, forced work and the extraction of bodily organs (since then regulated in Article 177 bis) from that of smuggling, while still maintaining in force Article 318 bis, in spite of its obsolescence in the new legal framework. But the confusion between the 
smuggling of migrants and trafficking in human beings is still evident in some governmental tools. For example, the National Action Plan Against Human Trafficking for Sexual Exploitation 2008-2012 (Plan integral de lucha contra la trata de seres humanos con fines de explotación sexuah, approved in December 12,2008, in spite of emphasizing the importance of distinguishing trafficking in human beings from the smuggling of migrants, stated that 'both trafficking and smuggling occur through causes established by irregular migration networks'. Following this trend, the National Strategy against Organised Crime for 2011-2014 (Estrategia Española contra el Crimen Organizado 2011-2014) included human trafficking as one of the crimes to be combated as a priority, ${ }^{97}$ but linked it with the fight against illegal migration (GRETA 2013: 15).

\section{Conclusion}

The inadequacy of the Spanish legal framework with regards to the obligations to identify, assist and protect victims of trafficking is directly connected with a governmental focus of Spain's anti-trafficking action on sexual exploitation of women and girls, on the one hand, and the combat against illegal migration on the other hand, rather than assisting and protecting all victims of trafficking for all forms of exploitation. In order to ensure the implementation of European standards we should take into account why the Spanish legal culture is still influenced by these two factors, so that we can decide the priority that must be given to proposals elaborated to improve efforts made by Spain in the fight against human trafficking. The Spanish policy response to human trafficking shows an over-concentration on sexual exploitation and migration control, locating law enforcement at the centre of the strategic response.

Perhaps it is time to defy the established criminal policy narratives which structure the legal interventions and the implementation of policies regarding human

\footnotetext{
${ }^{97}$ Human trafficking is usually perceived as an issue related to organised crime. This is also the case in the European Union, where the Directive says that human trafficking is a serious crime 'often committed within the framework of organised crime'. The same focus is assumed in Spain. Conversely, human trafficking would be better understood 'as a crime often perpetrated by people known to or, in many cases, related to the victims...' (IPPR 2013: 4). Critically on this regard, Spencer (2014).
} 
trafficking in both the European and national context, and pay attention to other narratives that have been trying to be heard. These oppositional narratives offer a different analysis to that of the dominant discourses. Although until now they have featured little in policymaking discussions, an increasing body of evidence suggests that 'policy is structured around a set of questions that have probably more to do with anxieties concerning migration and prostitution than they have with an anxiety over trafficking, for as Spanger (2011) has noted the dominant discourses are most often concerned with constructions of morality' (Spencer, 2014, p. 306).

\section{References}

1. Aradau C (2004) The Perverse Politics of Four-Letter Words: Risk and Pity in the Securitisation of Human Trafficking. Millenium: Journal of International Studies 33(2): 251-277.

2. Aronowitz A A (2011) Smuggling and trafficking in human beings: the phenomenon, the markets that drive it and the organizations that promote it. European Journal of Criminal Policy and Research 9(2): 163-195.

3. Carracedo Bullido R (2001) Legislación penal española. In Dirección General de la Mujer de la Comunidad de Madrid (ed) Simposio internacional sobre prostitución y tráfico de mujeres con fines de explotación sexual. Madrid: Dirección General de la Mujer de la Comunidad de Madrid, 149-159.

4. CITCO (2013) Balance 2013 de la lucha contra la trata de seres humanos con fines de explotación sexual. Available at http://www.interior.gob.es/prensa/balances-e-informes/2013

5. CITCO (2014) Balance de la Lucha contra el Crimen Organizado. Available at http://www.interior.gob.es/prensa/balances-e-informes/2014

6. CITCO (2015) Balance 2015 de prevención y lucha contra la trata de seres humanos en España y avance del Informe 2015 sobre los delitos de odio. Available at http://www.interior.gob.es/prensa/balances-e-informes/2015

7. Daunis Rodríguez A (2010) Sobre la urgente necesidad de una tipificación autónoma e independiente de la trata de personas. InDret: Revista para el Análisis del Derecho 1/2010: 1-44.

8. Daunis Rodríguez A (2013) El delito de trata de seres humanos. Valencia: Tirant lo Blanch. 
9. Daunis Rodríguez A (2014) El enfoque trafiquista y la perspectiva de género en la prostitución y la trata de seres humanos. In Laurenzo Copello P and R Durán Muñoz (eds) Diversidad cultural, género y Derecho. Valencia: Tirant lo Blanch, 631-664.

10. Defensor del Pueblo (2012) La trata de seres humanos en España: víctimas invisibles. Madrid: Defensor del Pueblo.

11. Defensora del Pueblo (2014) Comparecencia de 11 de junio de 2014, de doña Soledad Becerril Bustamante, Defensora del Pueblo, ante la Subcomisión para el análisis y estudio de la trata de seres humanos con fines de explotación sexual, constituida en el seno de la Comisión de Igualdad del Congreso de los Diputados, para informar en relación con el objeto de la misma. Available at https://www.defensordelpueblo.es/wpcontent/uploads/2015/05/2014_11_junio_Defensora_Trata.pdf

12. Delegación del Cobierno para la Violencia de Género (2015) Apoyando a las victimas de trata. Las necesidades de las mujeres víctimas de trata con fines de explotación sexual desde las entidades especializadas y profesionales involucrados. Propuesta para la sensibilización contra la trata. Madrid: Ministerio de Sanidad, Servicios Sociales e Igualdad.

13. Delegación del Gobierno para la Violencia de Género (2016) Boletín Estadístico Anual 2015. Madrid: Ministerio de Sanidad, Servicios Sociales e Igualdad.

14. Doezema J (2000) Loose Women or Lost Women? The Re-Emergence of the Myth of White Slavery in Contemporary Discourses of Trafficking in Women. Gender Issues 18(1): 23-50.

15. Doezema J (2010) Sex Slaves and Discourse Masters. The Construction of Trafficking. London-New York: Zed Books.

16. European Parliament (2016) Trafficking in Human Beings from a Gender Perspective. Directive 2011/36/EU. European Implementation Assessment. Brussels: Ex-Post Impact Assessment Unit.

17. Eurostat (2015) Trafficking in human beings. Luxembourg: Publications Office of the European Union.

18. Garaizábal C (1991) La prostitución: Un debate abierto. In Forum de Política Feminista (ed) Prostitución: Debate y propuestas del movimiento feminista. Madrid: Forum de Política Feminista: 6-10. 
19. GRETA (2013) Report concerning the implementation of the Council of Europe Convention on Action against Trafficking in Human Beings by Spain. First evaluation round. Strasbourg: Secretariat of the Council of Europe Convention on Action Against Trafficking in Human Beings.

20. Gutiérrez García A (2015) La trata de mujeres con fines de explotación sexual. Una clase especifica de violencia de género. In Gallardo Rodríguez $A$ and $M$ del Pozo Pérez (eds) ¿Podemos erradicar la violencia de género? Análisis, debate y propuestas. Granada: Comares, 105-118.

21. Iglesias Skulj A (2011) El control penal de las trabajadoras del sexo en el ámbito de las politicas contra la trata de mujeres con fines de explotación sexual (el caso español). Derecho Penal y Criminología 32(92): 22-41.

22. Iglesias Skulj A (2012) Sistema penal y perspectiva de género: trabajo sexual y trata de personas. Granada: Comares.

23. Institute of Public Policy Research (2013) Beyond Borders. Human Trafficking from Nigeria to the UK. London: IPPR.

24. Jurado Román N (2010) Trata de blancas versus violencia de género 0 respuesta a una demanda social. In Avilés Gómez M (ed) Delitos y delincuentes: cómo son, cómo actúan. Alicante: Editora Club Universitario, 305-320

25. León FJ de (2010) Spanish legislation against trafficking in human beings: punitive excess and poor victims assistance. Crime, Law and Social Change 54(5): 381-409.

26. Maqueda Abreu ML (2009a) Prostitución, Feminismos y Derecho Penal. Granada: Comares.

27. Maqueda Abreu ML (2009b) A propósito de la trata y de las razones que llevan a confundir a I@s migrantes con esclav@s. In Carbonell Mateu JC, JL González Cussac and E Orts Berenguer (eds) Constitución, derechos fundamentales y sistema penal. Semblanzas y estudios con motivo del setenta aniversario del Prof. Vives Antón. Valencia: Tirant lo Blanch, 1244-1260.

28. Nelken D (ed) (1997) Comparing Legal Cultures. Aldershot: Dartmouth.

29. Nelken D (2004) Using the Concept of Legal Culture. Australian Journal of Legal Philosophy 29: 1-26.

30. Nelken D (2010) Human Trafficking and Legal Culture. Israe/ Law Review 43(3): 479-513.

31. Nelken D (2014) Comparative Legal Cultures. In Bruinsma G and D Weisburd (eds) Encyclopedia of Criminology and Criminal Justice. Volume 2. C. New York: Springer, 458-467. 
32. Nelken D and J Feest (eds) (2001) Adapting Legal Cultures. Oxford: Hart.

33. Outshoorn J (2005) The Political Debates on Prostitution and Trafficking of Women. Social Politics: International Studies in Gender, State \& Society 12(1): 141-155.

34. Pineda E (1995) Algunas reflexiones sobre el estado actual del feminismo en España. Género y Sociedad 3: 95-116.

35. Pozuelo Pérez L (2005) Tráfico de personas y explotación sexual. In Bacigalupo $S$ and $M$ Cancio Meliá (eds) Derecho penal y politica transnacional. Barcelona: Atelier, 417-440.

36. Puente Aba LM and A Iglesias Skulj (2015) The Spanish Action Plan Against Trafficking in Women: Policies and Outcomes (2008-2011). In Guia MJ (ed) The Illegal Business of Human Trafficking. Heidelberg et al.: Springer, 71-86.

37. Spencer J (2014) Human trafficking policy making and the politics of international criminal justice. In Van Duyne PC, J Harvey, GA Antonopoulos, K von Lampe, Maljević and A Markovska (eds) Corruption, greed and crime money. Sleaze and shady economy in Europe and beyond. Oisterwijk: Wolf Legal Publishers, 291-312.

38. UNODC (2016) Global Report on Trafficking in Persons 2016. Vienna: United Nations Office on Drugs and Crime.

39. Valiente C (2004) State feminism and central state debates on prostitution in post-authoritarian Spain. In Outshoorn J (ed) The Politics of Prostitution. Women's Movements, Democratic states and the Clobalisation of Sex Commerce. Cambridge: Cambridge University Press, 205-224.

40. Villacampa Estiarte C (2006) Normativa europea y regulación del tráfico de personas en el Código penal español. In Rodríguez Mesa MJ and LR Ruiz Rodriguez (eds) Inmigración y sistema penal. Retos y desafios para el siglo XXI. Valencia: Tirant lo Blanch, 69-108.

41. Villacampa Estiarte C (2011) El Delito de Trata de Seres Humanos. Una Incriminación Dictada desde el Derecho Internacional. Cizur Menor: Thomson Reuters Aranzadi. 